\title{
Epstein-Barr Virus and Human Diseases: Recent Advances in Diagnosis
}

\author{
MOTOHIKO OKANO, ${ }^{1 *}$ GEOFFREY M. THIELE,${ }^{1}$ JACK R. DAVIS,${ }^{1}$ HELEN L. GRIERSON,${ }^{1}$ AND \\ DAVID T. PURTILO ${ }^{1.2}$ \\ Departments of Pathology and Microbiology ${ }^{1}$ and Pediatrics and Eppley Institute for Research in Cancer and Allied \\ Diseases, ${ }^{2}$ University of Nebraska Medical Center, Omaha, Nebraska 68105-1065
}

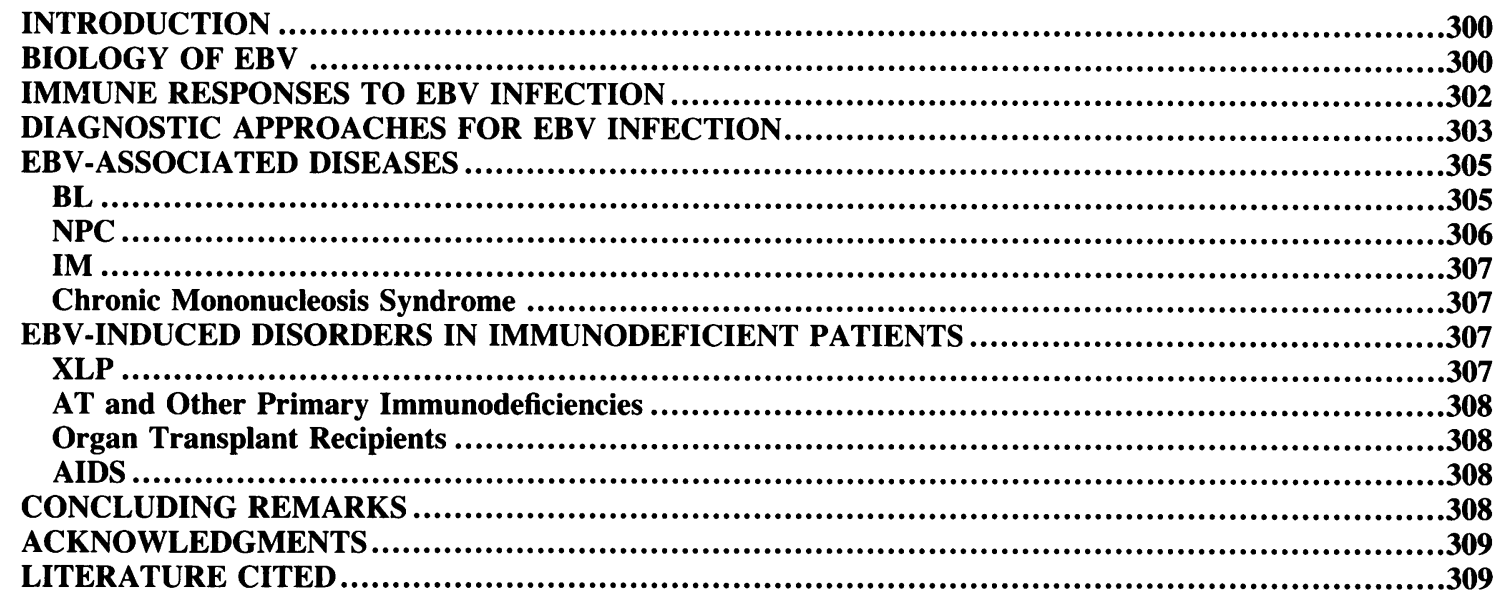

\section{INTRODUCTION}

The Epstein-Barr virus (EBV) was initially discovered by electron microscopy within a cultured African Burkitt's lymphoma (BL) cell line in 1964 (Fig. 1) (23). EBV, a B-lymphotropic virus, is widespread among different populations. Infection is generally established in early childhood in most parts of the world and remains silent throughout a person's life $(20,42)$. However, a spectrum of clinical entities with EBV involvement has been defined (20,35, 42, $74,77)$. When uninfected adolescents and young adults are exposed to EBV, approximately two-thirds of them manifest infectious mononucleosis (IM) $(20,42,74,77)$. This casual role of EBV in IM is well documented. Another category of possible EBV-associated diseases is the chronic mononucleosis/chronic fatigue or chronic EBV infection syndrome without clearly defined underlying diseases $(53,92,99)$. In addition, nasopharyngeal carcinoma (NPC) is another human malignancy highly associated with this virus $(20,45,74$, $77,78,106)$

Like other herpesviruses, EBV may also be reactivated in the immunologically compromised host. These individuals often handle EBV quite well (41). However, EBV-carrying lymphoproliferation or lymphomas have been recently noted in patients with both primary and acquired immunodeficiencies $(35,74,77)$. These lymphoproliferative disorders range from benign polyclonal B-cell hyperplasias without cytogenetic abnormalities to more classic monoclonal malignant lymphomas with clonal chromosomal abnormalities $(35,74$, 77). The immunopathogenetic mechanisms that may permit EBV to induce such a diverse array of diseases are currently under investigation. Likely, an individual's immunocompe-

\footnotetext{
* Corresponding author.
}

tence determines whether or not a potentially life-threatening disease occurs, rather than the usual silent infection $(74,77)$. Cytogenetic alterations in virus-infected cells are another major factor in determining the outcome of EBV infection, specifically, the emergence of a monoclonal malignant lymphoma (56).

In this overview, we first focus on various aspects of the biology of EBV; second, the immune response to the virus that may determine the spectrum of lymphoproliferative diseases; and third, diagnostic approaches to active EBV infection. Finally, classical disorders associated with the virus are summarized, and a spectrum of unusual manifestations of EBV infection is considered.

\section{BIOLOGY OF EBV}

EBV is one of the six known herpesviruses. This deoxyribonucleic acid (DNA) lymphotropic virus replicates in oropharyngeal epithelial cells (Fig. 1). Infectious and oncogenic properties of the virus have been investigated extensively $(20,74,77)$. The DNA of EBV is a linear, doublestranded molecule of approximately $170 \times 10^{3}$ nucleotide base pairs (17). The molecular structure of EBV DNA based on detailed restriction endonuclease maps is shown in Fig. 2. Briefly, the genome consists of unique tandemly repeated DNA elements. Since the number of tandem repeats varies among different EBV isolates and among molecules from each isolate, it is useful to consider the genome as being organized as TR (terminal repeat)-U(unique region)1-IR (internal repeat)1-U2-IR2-U3-IR3-U4-IR4-U5-TR (17).

In vitro, EBV selectively infects and immortalizes human and some primate B lymphocytes polyclonally and induces the production of immunoglobulin (83). EBV receptors are present on nearly all $\mathrm{B}$ lymphocytes and correspond to the 


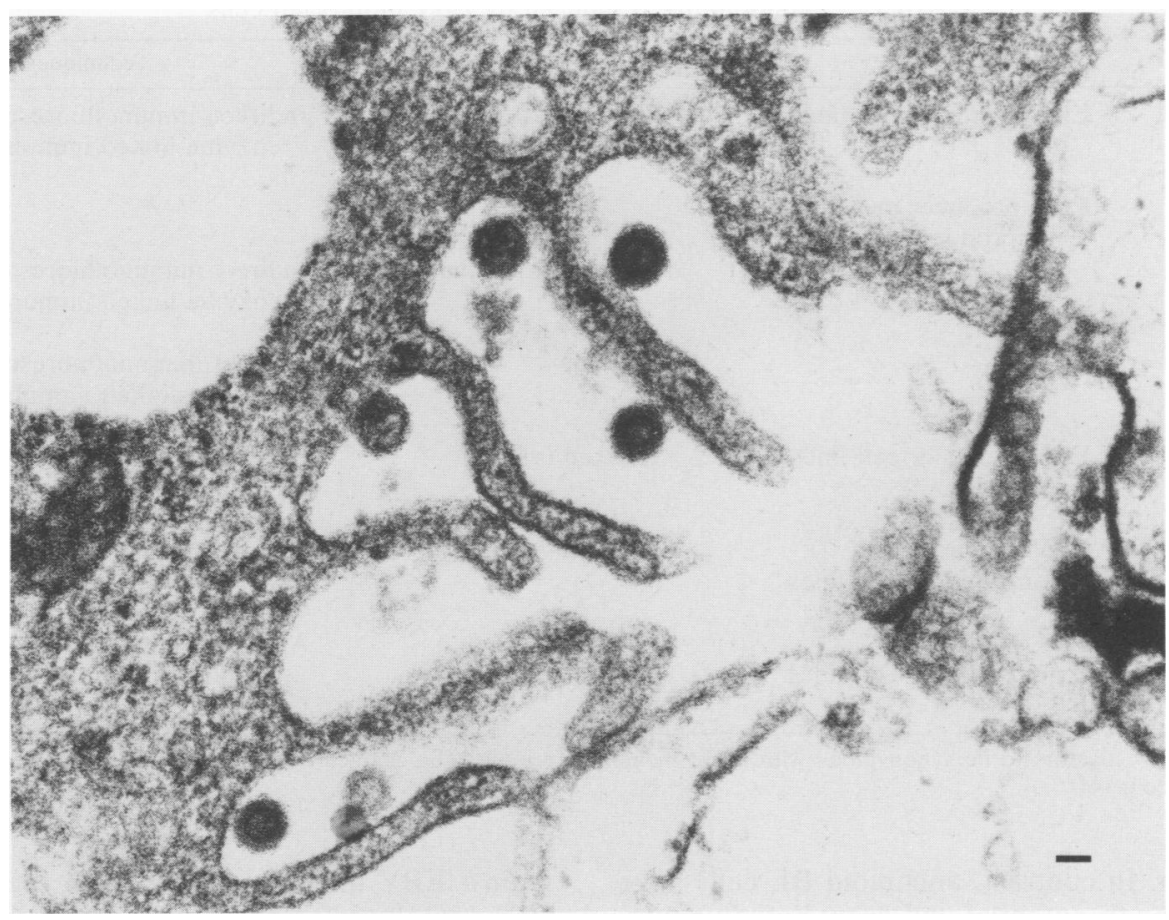

FIG. 1. Electron micrograph of a tonsillar epithelial cell with adherent EBV particles. Bar, $100 \mathrm{~nm}$.

C3d component of complement (CR2) $(27,51)$. Shown in Table 1 are the major EBV-related antigens in infected lymphocytes. They are expressed chronologically following infection. During the lytic (virus-productive) cycle, the synthesis and expression of EBV-determined nuclear antigen (EBNA) occur several hours after infection and may be preceded or accompanied by the functional presence of lymphocyte-detected membrane antigen $(52,61)$. Membrane antigen and early antigen (EA) expression follows. Next, viral DNA synthesis commences; and finally, viral capsid antigen (VCA) and late membrane antigen are produced for the assembly and release of infectious virus particles (81). More frequently, a latent (nonproductive) infection occurs in B lymphocytes. Herein the virus is incorporated into and replicated with the host DNA, but remains in the latent state in immortalized or transformed B cells expressing only EBNA or lymphocyte-detected membrane antigen or both (81).

Following EBV infection, first EBNA and then cellular DNA and protein syntheses occur. The infected cells are subsequently immortalized and begin to proliferate continuously (81). Although EBV infection results in a polyclonal activation of B lymphocytes, the virus differs significantly from other B-cell activators, such as pokeweed mitogen. The latter, a T-cell-dependent B-cell mitogen, stimulates immunoglobulin-producing B lymphocytes. EBV, however, is not T-cell dependent and stimulates primarily B cells (83). Like lymphocyte-detected membrane antigen- and EBNA-positive permanent lymphoblastoid cell lines in vitro, a permanent carrier state in which small numbers of latently infected $B$ cells circulate in seropositive individuals might be established (57). Latency is a unique characteristic of all herpesviruses (82). The molecular mechanisms that arrest these viruses in the latent state or allow them to enter the lytic cycle are unknown. The reentry of these latently infected cells into the lytic cycle may result in the reactivation of EBV infections. Also, cytogenetic alterations in EBV-infected $B$ cells have been hypothesized to spawn the outgrowth of malignant transformed cell clones, resulting in a monoclonal BL (56).

The nude mouse has been used routinely to evaluate whether EBV-infected cells have malignant potential. For example, human diploid lymphoblastoid cells immortalized by EBV can grow in the brain of nude mice but not in

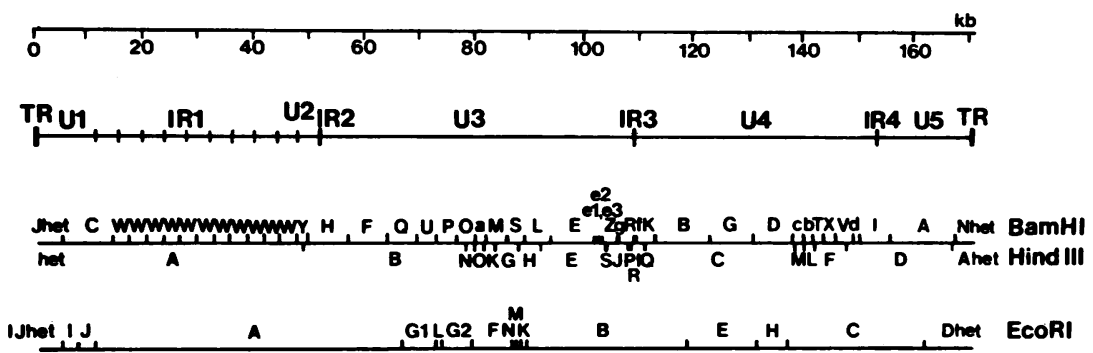

FIG. 2. Schematic representation of a restriction endonuclease map of EBV genome. TR, Terminal repeat; IR, internal repeat; U, unique region. 
TABLE 1. Major antigens induced by EBV in infected cells

\begin{tabular}{|c|c|c|c|}
\hline Viral antigens & Source & Fixation (if noted) & Techniques for detection \\
\hline VCA & EBV producer cell lines & Acetone & $\begin{array}{l}\text { Indirect immunofluorescence, immunoblotting, } \\
\text { enzyme-linked immunosorbent assay }\end{array}$ \\
\hline EA & $\begin{array}{l}\text { EBV producer or activated } \\
\text { nonproducer cell lines }\end{array}$ & & \\
\hline EA-D & & Acetone or methanol & $\begin{array}{l}\text { Indirect immunofluorescence, immunoblotting, } \\
\text { enzyme-linked immunosorbent assay }\end{array}$ \\
\hline EA-R & & Acetone & $\begin{array}{l}\text { Indirect immunofluorescence, immunoblotting, } \\
\text { enzyme-linked immunosorbent assay }\end{array}$ \\
\hline Membrane antigen & EBV producer cell lines & Unfixed (viable) & $\begin{array}{l}\text { Indirect immunofluorescence, immunoblotting, } \\
\text { enzyme-linked immunosorbent assay }\end{array}$ \\
\hline $\begin{array}{l}\text { Lymphocyte-detected } \\
\text { membrane antigen }{ }^{a}\end{array}$ & $\begin{array}{l}\text { EBV producer or } \\
\text { nonproducer cell lines }\end{array}$ & Unfixed (viable) & Lymphocytotoxicity assay \\
\hline EBNA & $\begin{array}{l}\text { EBV producer or } \\
\text { nonproducer cell lines }\end{array}$ & Acetone-methanol & $\begin{array}{l}\text { Anticomplement immunofluorescence, } \\
\text { immunoblotting, enzyme-linked } \\
\text { immunosorbent assay }\end{array}$ \\
\hline
\end{tabular}

${ }^{a}$ Considered by some investigators to be synonymous with latent membrane protein. This antigen(s) on the surface of infected $B$ cells is the target for EBV-specific cytotoxic T cells (44).

subcutaneous tissues. In contrast, aneuploid BL cells have greater malignant growth potential and grow both subcutaneously and intracerebrally in nude mice (65). These experimental findings partially explain why opportunistic malignant lymphoma in immunodeficient patients tends to occur in the brain.

The major route of transmission of EBV is through the saliva and very rarely by blood transfusion $(31,32)$. Some 15 to $20 \%$ of young adults in the United States are virus shedders (13). In immune suppressed persons, viral shedding is very common. Whether EBV replicates in oropharyngeal epithelial cells, lymphoid tissue, or the parotid gland, before being released into the saliva, has been of particular interest. The B95-8 and P3HR-1 laboratory strains of EBV do not infect epithelial cell cultures. In contrast, wild-type virus from fresh oropharyngeal washings of a patient with IM was found to infect epithelial cell cultures (88). Furthermore, a homogenous episomal population of EBV was detected in lesions of NPC (78). This observation might explain the link between EBV and NPC. It now appears that oropharyngeal epithelial cells are the likely source of the infectious transmissible virus leading to the subsequent infection and immortalization of B lymphocytes (87).

It was generally accepted that no significant difference was observed in the EBV genome of viruses isolated from patients with different diseases (i.e., BL, NPC, or IM or normal persons) and from different regions of the world ( 7 , 8). However, recent reports have demonstrated the existence of minor differences in types of EBV based on their restriction endonuclease digestion cleavage patterns $(1,55$, $105)$. The biologic significance of this variation is still unknown (55).

\section{IMMUNE RESPONSES TO EBV INFECTION}

Primary EBV infections are commonly asymptomatic in childhood. In general, viruses tend to cause less serious illness when infection occurs in young children than when it occurs in adults $(20,74,77)$. Acquisition of the virus during adolescence or early adulthood, however, causes IM in the majority of persons $(20,74,77)$. The first line of defense against EBV infection comes from the interferon liberated by the virally infected $B$ cells and the $T$ cells responding to the virus $(77,98)$. Interferon may control EBV-induced B-cell lymphoproliferation by antiviral replication activity, antilymphocytic proliferative response, and boosting of natural killer (NK) cell activity $(77,103)$. Interferon and NK cells may act synergistically to protect against EBV. It is now known that NK cells do not require prior sensitization and memory to kill target cells. EBV-specific cytotoxic T cells have been detected in the peripheral blood of individuals with IM and may be directed against lymphocytedetected membrane antigen, which is expressed on the surface of EBV-carrying cells (95). The EBV-specific cytotoxic $\mathrm{T}$ cells are considered to be the most important factor in controlling an EBV-induced B-cell proliferation. Also, impairment of normal $\mathrm{T}$-cell responses (i.e., anergy) is associated with B-cell proliferation evoked by EBV infection. Activation of suppressor $\mathrm{T}$ cells is responsible for this anergy. The majority of the atypical lymphocytes found in the peripheral blood during IM are suppressor T cells (100). Antibody-dependent cell-mediated cytotoxicity, the titers of which are prognostic in patients with BL and NPC, may also be an important immune response to $\mathrm{EBV}$, but the precise mechanism is unknown (72). Memory $T$ cells can be assessed by the regression assay in a person by measuring outgrowth inhibition of autologous EBV-infected B cells (64). In seronegative individuals, these memory $T$ cells have been shown not to be present. The normal immune events which follow EBV infection are shown in Fig. 3.

The humoral responses to EBV infection that develop are characteristic antibody responses to virally determined antigens $(20,42)$. A current primary EBV infection is defined serologically by the early appearance of circulating antiVCA immunoglobulin M (IgM) antibodies and their subsequent decrease to nondetectable levels. Almost concurrently, an increase of anti-VCA IgG antibody appears which may continue increasing and in normal persons persists for life. Anti-EA-D (diffuse EA component) IgG antibodies are developed transiently in $80 \%$ of affected individuals. AntiEBNA IgG antibody is absent during acute infection. It is 


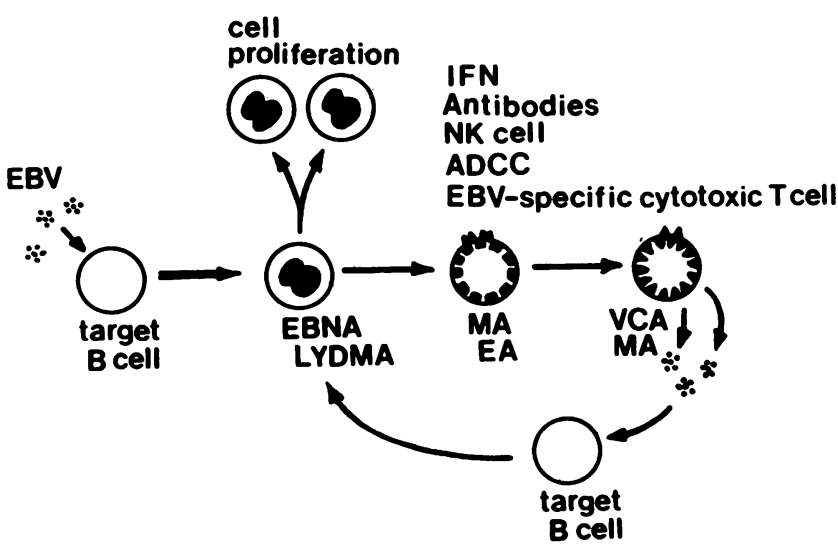

FIG. 3. Diagram indicating immune events of $E B V$ infection. LYDMA, Lymphocyte-detected membrane antigen; MA, membrane antigen; IFN, interferon; ADCC, antibody-dependent cellmediated cytotoxicity.

detected weeks to months later and persists for life. AntiEA-R (restricted EA component) IgG antibodies are rarely present in the acute phase of IM, but in many cases appear transiently during late convalescence and in some silent primary EBV infections in childhood or more chronic cases of EBV infection, i.e., BL. In general, reactivation of EBV infection is defined by elevated antibody titers to VCA IgG, EA-D (EA-R in cases of BL), and the preexistence of anti-EBNA IgG antibodies. A past EBV infection is identified by the absence of anti-VCA IgM antibodies and presence of IgG antibodies against both VCA and EBNA.

Immunologically compromised individuals demonstrate either unusually low or high antibody titers to EBV-specific antigens and a lack of antibody to EBNA is often observed $(41,74,77)$, especially in children with primary immunodeficiency disorders. The mechanisms that control or decontrol production of the various antibodies remain to be elucidated. However, recent studies have indicated that the control mechanisms for production of antibodies to VCA and EA are different from those for antibody response to $\operatorname{EBNA}(41,42)$. A deficiency or dysfunction of the immunosurveillance system against EBV infection permits productive cycles of viral replication, which lead to production of EA, and VCA antibodies. Most likely, the lack of antibody to EBNA is due to a decreased or absent immune $\mathrm{T}$-cell function against EBV. This cytotoxic immune response is thought to be necessary for the release of EBNA from the nuclear membrane of infected B cells, which then stimulates antibody production $(41,42)$.

EBNA is now known to be produced by a complex of numerous genes. First EBNA-1 and EBNA-2 were identified, followed by EBNA-3 and, most recently, EBNA-4, EBNA-5, and EBNA-6 (21; A. Ricksten, B. Kallin, H. Alexander, J. Dillner, R. Fahraeus, G. Klein, R. Lerner, and L. Rymo, Proc. Natl. Acad. Sci., in press). EBNA-1, the main EBNA component which is encoded by the BamHI K fragment of the viral genome, seems to be required for maintenance of the virus in episomal form (102). EBNA-2, encoded by the BamHI Y and $\mathrm{H}$ fragments, appears to be involved in primary B-cell transformation (24). These antigens are stably expressed in mouse fibroblasts or human lymphoid cells following transfection by DNA fragments containing the exons coding for EBNA-1 or EBNA-2. These transfected cultures are useful for the detection and titration of antibodies to these two components (43). IgG antibodies to EBNA-1 appear long after IgG antibodies to EBNA-2, increase gradually in titer, and in time exceed the level of EBNA-2 antibodies. These antibodies then persist indefinitely, while antibodies to EBNA-2 decline to lower persistent levels or become nondetectable (43).

The relationship of EBV to disease has been further established through immunological studies, staining of affected tissue for EBNA, and DNA hybridization studies that demonstrate EBV-specific DNA sequences in biopsy specimens.

\section{DIAGNOSTIC APPROACHES FOR EBV INFECTION}

The Paul-Bunnell-Davidsohn test detects IgM heterophil antibodies that have the ability to agglutinate sheep or horse erythrocytes and are further differentiated from heterophil antibodies associated with other diseases by their significant absorption to beef erythrocytes but not guinea pig kidney $(19,71)$. Simple and rapid qualitative slide tests for heterophil antibodies utilizing horse erythrocytes as agglutination indicator cells are widely available (94). These heterophil antibodies appear in the serum of approximately $85 \%$ of adult patients with IM (25). Infections by cytomegalovirus, hepatitis virus, rubella virus, herpes simplex virus, adenovirus, and Toxoplasma gondii may cause an IM-like illness, termed the mononucleosis syndrome, but can be differentiated from IM by serological methods. In addition, patients with these infectious agents rarely exhibit positive heterophil antibodies $(20,25)$. In the differential diagnosis of the mononucleosislike diseases, the age of the patient can be helpful. IM-like illness is more likely to be due to EBV in patients in their teens, while cytomegalovirus infection is more prevalent in early middle age. $T$. gondii infections are less frequent and occur much later in life (25). Children less than 4 years of age often fail to develop heterophil antibodies $(28,94)$.

EBV-specific serodiagnostic tests that use immunofluorescence testing are required to diagnose heterophil-antibodynegative cases of IM or IM-like illnesses. These tests are also essential for heterophil-antibody-positive patients with atypical manifestations, especially patients with lymphoproliferative lesions and lymphomas with immunodeficiency.

The serodiagnosis of many viral infections rests on the demonstration of a fourfold or greater increase in antibody titers between the acute and convalescent phases of illness. In general, in suspected EBV infection, a single serum specimen is tested. The interpretation of serological tests is based on the profile of antibody titers against a panel of four antigens: VCA, EA-D, EA-R, and EBNA. The antibodies to VCA, EA-D, and EA-R are measured by the indirect immunofluorescence assay; anti-EBNA antibodies must be measured by the anticomplement immunofluorescence method $(20,41,42,77)$. Recently, enzyme-linked immunosorbent assays to detect antibodies specific for EBV-related antigens have been developed (59). For example, synthetic peptide for EBNA-1 has been produced and utilized in an enzymelinked immunosorbent assay that is more sensitive and specific than anticomplement immunofluorescence (97). The antibody profiles for the different antigens demonstrate a characteristic pattern for each of the EBV-associated diseases, as well as for silent primary or persistent latent infections. As previously described, the humoral response to primary EBV infection occurs rapidly. Most (>80\%) symptomatic patients show near-peak antibody titers of IgG and IgM to VCA when first examined. Most of the patients transiently develop antibodies to EA-D, but antibodies to 
TABLE 2. Serologic profiles of EBV antibodies in patients with EBV-associated diseases and healthy controls ${ }^{a}$

\begin{tabular}{|c|c|c|c|c|c|c|c|c|}
\hline \multirow{3}{*}{ Condition or disease } & \multicolumn{8}{|c|}{ Antibodies } \\
\hline & \multicolumn{3}{|c|}{ VCA } & \multicolumn{2}{|c|}{ EA-D } & \multirow{2}{*}{$\begin{array}{l}\text { EA-R } \\
\text { (IgG) }\end{array}$} & \multirow{2}{*}{$\begin{array}{c}\text { EBNA } \\
\text { (IgG) }\end{array}$} & \multirow{2}{*}{$\begin{array}{l}\text { Heterophil } \\
\text { (IgM) }\end{array}$} \\
\hline & IgM & IgG & $\lg A$ & IgG & $\operatorname{IgA}$ & & & \\
\hline Not infected & - & - & - & - & - & - & - & - \\
\hline Silent primary infection & + & + & - & $+1-$ & - & $+1-$ & - & $+1-$ \\
\hline Past infection & - & + & - & $+1-$ & - & - & + & - \\
\hline Reactivation with immunodeficiency & $+1-$ & ++ & $+1-$ & ++ & $+1-$ & $+1-$ & $+1-$ & $+1-$ \\
\hline IM & + & ++ & - & + & - & $+1-$ & - & + \\
\hline BL & - & ++ & - & $+1-$ & - & ++ & + & - \\
\hline NPC & - & ++ & + & ++ & + & - & + & - \\
\hline
\end{tabular}

${ }^{a}++$, Elevated antibodies; + , positive antibodies; - , negative antibodies.

EBNA are absent because they appear only several weeks or months after the onset of disease (39). Should confirmation of the diagnosis be needed, tests of a subsequent serum specimen from the patient should reveal a decline or disappearance of the IgM antibodies to VCA and of the IgG antibodies to EA-D, as well as emergence of antibodies to EBNA. Anti-EA-R antibodies are rarely present in the acute phase of IM, but in many cases appear transiently during late convalescence and in some primary infections in children $(28,47,94)$. In general, IgM antibodies to VCA disappear within 1 to 2 months of the onset of IM, while IgG antibodies to VCA persist for life and can be used to indicate immunity. Assay of IgM antibody to VCA may produce false-negative or false-positive test results; for example, presence of rheumatoid factor can give a false-positive IgM VCA titer (40). If this is suspected (i.e., when an EBNA titer is present), the sera should be absorbed for rheumatoid factor, using latex particles, and the titer should be remeasured (40).

The precise antibody titers achieved and the time required for developing the full spectrum of antibodies vary with the individual humoral response during the infection. However, lifelong presence of IgG antibodies to VCA and EBNA reflect latency of the virus.

Under normal circumstances, the antibody response to EBV is tightly regulated by the host immune systems. Therefore, the serologic profiles of healthy individuals are relatively stable, whereas patients with various immunodeficiency disorders, whether genetic or iatrogenic, show abnormal EBV serologic profiles $(41,42,74,77)$. In the majority of such cases, elevated titers of anti-VCA, anti-EA$\mathrm{D}$, or anti-EA-R are detected, with or without concomitant changes in the titers to EBNA. The absence of antibody to EBNA has been noted in some patients with T-cell dysfunction (41). Table 2 shows the typical serologic profiles of healthy individuals and patients with EBV infection.

Serologic methods do not always correspond with the status of active EBV infection as they are indirect and depend on whether the patient has an intact immune system. For example, healthy individuals sometimes have elevated antibody titers without symptoms, but immunocompromised persons who develop disseminated EBV infection often do not exhibit the full spectrum of antibodies $(41,77)$. Some of these patients may lose their ability to produce EBV-specific antibodies when they develop hypogammaglobulinemia. Thus, antibodies may not reflect the influence of the viral genome at the cellular level.

Two other methods for analyzing the status of EBV infections involve the demonstration of a biologically active virus or the presence of viral antigens. In the majority of EBV-infected cells, the genome is latent; that is, mature virus is not replicated. To demonstrate the presence of this latent genome in human tissues, cells are examined for the presence of EBNA either directly by staining touch imprints of tissues and frozen sections of lesions or after in vitro cultivation of peripheral blood lymphocytes, lymphoid cells from lymphoproliferative lesions, and throat washings with cord lymphocytes $(36,57,77)$. Figure 4 shows the staining pattern of EBNA in a spontaneously established lymphoid cell line from a biopsy specimen of a cervical lymph node of a patient with massive lymphadenopathy associated with EBV infection.

Test for EBNA that use anticomplement immunofluorescence involve subjective interpretation and require that the tissues be in excellent condition before being stained. Because of these limitations, techniques of nucleic acid hybridization have been developed to demonstrate the presence of the viral genome in different tissues (2). Use of either Southern blot analysis or the slot-blot method to detect EBV genome in tissues offers clear advantages in documenting the association of EBV with diverse clinical conditions (2). Another molecular method is in situ hybridization, which is performed directly on cells from frozen sections of tissue (70). Immunoblotting can also be used to detect EBV-related antigens in tissues (21).

The presence of a virus in affected lesions does not absolutely establish that it is the etiologic agent of a disease, as it is possible that the virus is secondary to the disease and is just an opportunist. However, using nucleic acid hybridization techniques, EBV DNA is found only in tissues from patients with active EBV infection having neoplastic or other lymphoproliferative disorders, such as various lymphomas and lymphoproliferative lesions in patients with immunodeficiency syndromes. Normal lymphoid tissues do not contain detectable amounts of EBV genome (2). EBV DNA exists as a circular episome in those infected cells in which viral genome is present and in constant balance with host cellular DNA, but in which infectious virus particles are not produced. In permissive cells, infectious virus is actively produced and the viral DNA persists in a linear form (30). Recently, techniques to clarify whether one or both DNA forms are present in tissue have been developed. These techniques evolved because antiviral agents such as acyclovir (9[2-hydroxyethoxymethyl]guanine) inhibit the replication of linear EBV DNA, thus preventing the production of infectious virus (18).

The diagnosis of lymphoproliferative diseases or malignant lymphoma depends on histologic evaluation of tissue biopsies. However, distinguishing between malignant and benign disorders in lymphoid tissues remains a most difficult problem. Analysis of antigens on the surface or in the cytoplasm of lymphoid cells in tissue sections or in cell suspensions of biopsies assists in defining clonality (101). 


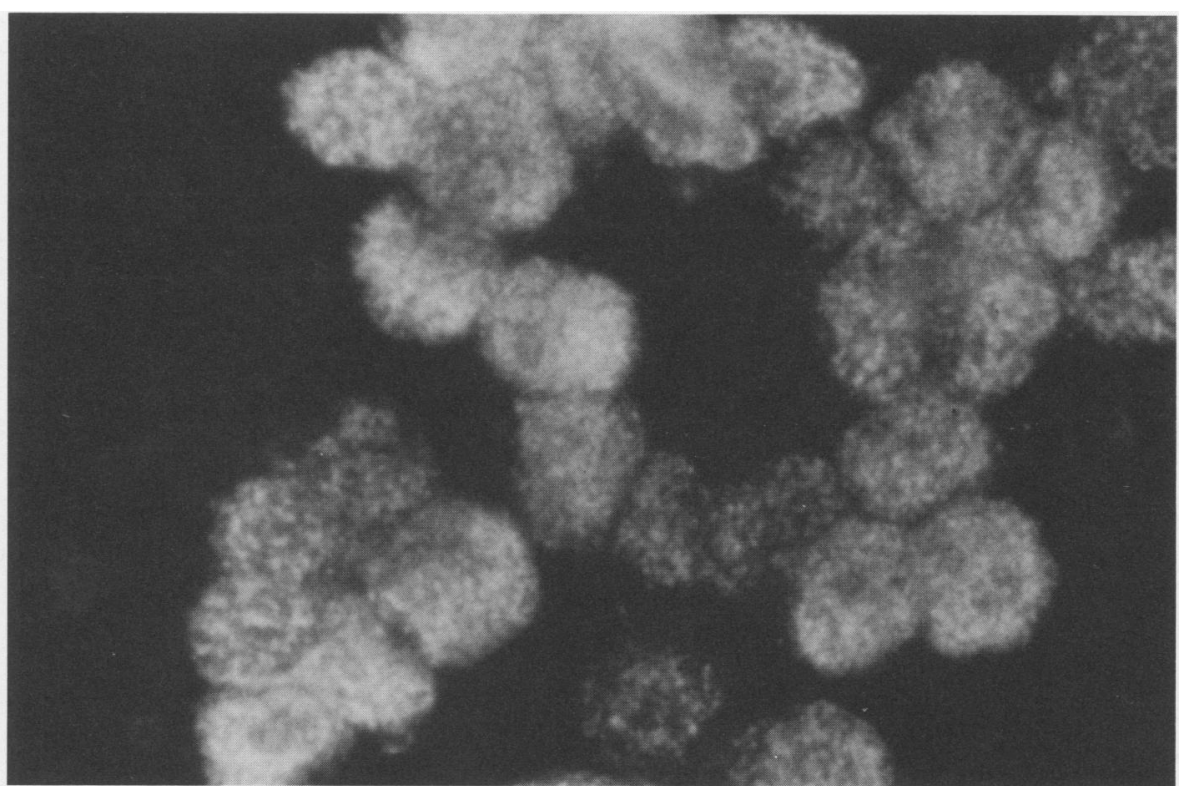

FIG. 4. EBNA-positive cells shown by anticomplement immunofluorescence in a spontaneously established cell line from a biopsy specimen of the cervical lymph node of a patient with massive lymphadenopathy associated with EBV infection.

However, malignant cells are often intermixed with various amounts of normal reactive cells. Uniform rearrangements of immunoglobulin or $\mathrm{T}$-cell receptor genes within clonal populations of $B$ or $T$ cells in lesions can be detected by Southern blot analysis $(15,29)$. Figure 5 shows a Southern blot analysis which detected EBV DNA and possible heavychain joining region $\left(\mathrm{J}_{\mathbf{H}}\right)$ gene rearrangement in affected tissues from a patient with EBV-associated lymphoproliferation.

The cellular oncogene, c-myc, has been shown to be activated or rearranged in BL. Such oncogene activation is accompanied by specific chromosomal translocations with $\mathrm{t}(8 ; 14), \mathrm{t}(2 ; 8)$, and $\mathrm{t}(8 ; 22)(76)$. Another proto-oncogene, fgr, related to the Gardner-Rasheed feline sarcoma virus, is activated by EBV infection (14; M. Okano, J. R. Davis, B. Brichacek, N. Yasuda, and D. T. Purtilo, Fed. Proc. 46:741, 1987). Identification of the activation or rearrangement of cellular oncogenes and specific chromosomal aberrations in affected lymphoid tissues may become an important diagnostic approach for assessing malignant lymphoid proliferative lesions. Diagnostic approaches for EBV infection are summarized in Table 3.

\section{EBV-ASSOCIATED DISEASES}

In this section, classical disorders and unusual manifestations associated with EBV infection are reviewed (Table 4).

\section{BL}

Denis Burkitt described the neoplasm now called BL in 1958 in the jaws and visceral organs of Ugandan children (9). The histopathological subtype is a poorly differentiated lymphoma. In the new working formulation of non-Hodgkin's lymphoma, BL belongs to the high-grade, malignant lymphoma, small noncleaved cell group (84). The presence of large histiocytes gives the lymphoma a "starry sky" picture. Both endemic and sporadic BL generally respond well to chemotherapy. The mean age of occurrence is around 8 years in the endemic areas, but about 16 years in the low-incidence areas (20). Males are predominantly affected.
Geographically, BL is distributed in equatorial Africa and New Guinea where holoendemic malaria occurs $(10,20)$. The incidence is about 10 per 100,000 at risk per year. More than $95 \%$ of cases are EBV genome positive (104). Some $80 \%$ of $\mathrm{BL}$ in nonendemic areas occurs sporadically without the presence of EBV genome. Patients with BL show

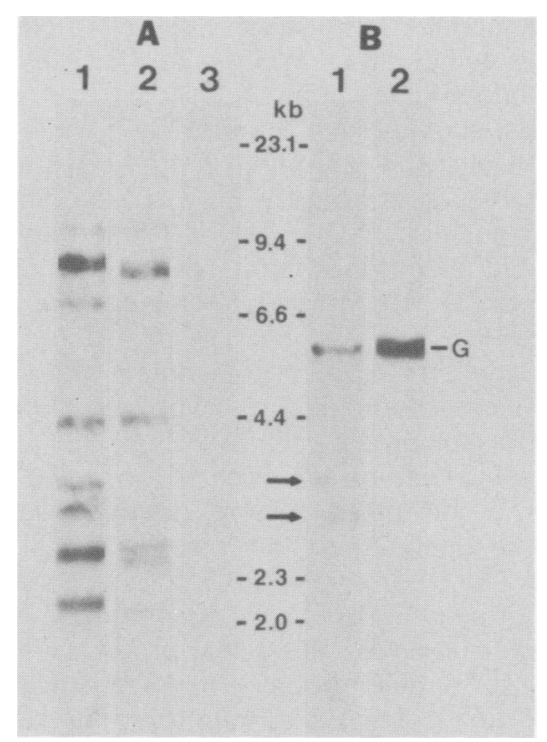

FIG. 5. Southern blot analysis of tissues for EBV genome and $J_{H}$ gene rearrangement in a patient with EBV-induced lymphoproliferative disorder. Each tissue was digested by Bam HI and HindIII. (A) EBV DNA was demonstrated with cosmid clones cM 302-23 and cM 301-99 (kindly supplied by E. Kieff, Harvard University, Boston, Mass.) of EBV (lane 1, lymph node; lane 2, Raji EBV-positive cell line; lane 3, EBV-negative human placenta). (B) $\mathrm{J}_{\mathrm{H}}$ gene rearrangement $\left(J_{H}\right.$ probe given by $P$. Leder, Harvard University) was also detected in same tissue (lane 1 , lymph node; lane 2 , human placenta). Arrows (between 2.3 and $4.4 \mathrm{~kb}$ ) indicate possible rearranged bands, and $\mathrm{G}$ shows germ line band. 
TABLE 3. Detection of EBV infection

\begin{tabular}{|c|c|}
\hline Test & Method \\
\hline \multicolumn{2}{|l|}{ Serology for EBV } \\
\hline VCA-IgG, IgM, IgA & Indirect immunofluorescence \\
\hline EA-D-IgG, IgA & Indirect immunofluorescence \\
\hline EA-R-IgG & Indirect immunofluorescence \\
\hline EBNA-IgG & $\begin{array}{l}\text { Anticomplement immunofluo- } \\
\text { rescence, enzyme-linked } \\
\text { immunosorbent assay }\end{array}$ \\
\hline Heterophil-IgM & $\begin{array}{l}\text { Paul-Bunnell-Davidsohn test or } \\
\text { rapid slide test }\end{array}$ \\
\hline \multicolumn{2}{|l|}{$\begin{array}{l}\text { Detection of EBV genome in } \\
\text { tissues }\end{array}$} \\
\hline EBV DNA & $\begin{array}{l}\text { Southern blot analysis, spot } \\
\text { hybridization, in situ } \\
\text { hybridization }\end{array}$ \\
\hline Detection of EBNA in tissue & $\begin{array}{l}\text { Anticomplement immunofluo- } \\
\text { rescence, immunoblotting }\end{array}$ \\
\hline $\begin{array}{l}\text { Culture of peripheral blood } \\
\text { lymphocytes, lymphoid cells } \\
\text { from lymphoproliferative } \\
\text { lesions, and throat washings } \\
\text { with cord lymphocytes }\end{array}$ & $\begin{array}{l}\text { Establishment of EBNA and/or } \\
\text { EBV genome-positive } \\
\text { lymphoblastoid cell lines }\end{array}$ \\
\hline $\begin{array}{l}\text { Analysis of EBV-specific } \\
\text { cytotoxic T-cell functions }\end{array}$ & $\begin{array}{l}\text { Lymphocytotoxicity assay, } \\
\text { regression assay }\end{array}$ \\
\hline
\end{tabular}

elevated VCA IgG antibody titers and positive IgG antibodies against EA-R (20). Prospective studies of children in the West Nile region of Uganda, at high risk for BL, showed elevated antibody titers to VCA-IgG in their sera years before onset of BL. Thus, a possible association between EBV and BL development was established (20). Depressed T-cell-mediated immune control of the EBV infection might be caused by activation of suppressor $\mathrm{T}$ cells by malaria infection. Moreover, continuous antigenic stimulation of EBV-infected B lymphocytes by malarial antigens may promote development of BL (10). However, another report has shown that malaria does not seem to influence immunological response to EBV infection, as measured by antibody titers to VCA (4).

Translocations between chromosome 8 and chromosome 14,2 , or 22 are found in karyotyped BL whether EBV genome is present or not $(56,76)$. The relevance of these reciprocal translocations seems to be linked to the expression of c-myc. In these tumors, the oncogene product appears to be qualitatively normal, but its production is deregulated. The common denominator in the translocations found in $\mathrm{BL}$ is a breakage in chromosome $8 \mathrm{q} 24$, which is the locus of c-myc and codes for nuclear proteins affecting DNA replication and transcription (76). Translocation brings c-myc genes adjacent to the immunoglobulin genes of chromosome 14 (heavy chain), 2 (kappa light chain), or 22 (lambda light chain) which regulate $\mathbf{B}$-cell differentiation (76).

At least three steps prevail during the pathogenesis of $\mathrm{BL}$ $(56,76)$ : (i) EBV infection provokes nonmalignant polyclonal B-cell proliferation; (ii) the development of T-cell immunodeficiency and B-cell proliferation is likely caused by continuous mitogenic activity by malarial antigens; and (iii) a specific chromosomal translocation occurs within a proliferating $\mathrm{B}$ cell, leading to monoclonal malignancy. The genetically altered cell outgrows normal cells due to enhanced
TABLE 4. Spectrum of classical EBV-associated diseases and disorders in immunologically compromised patients

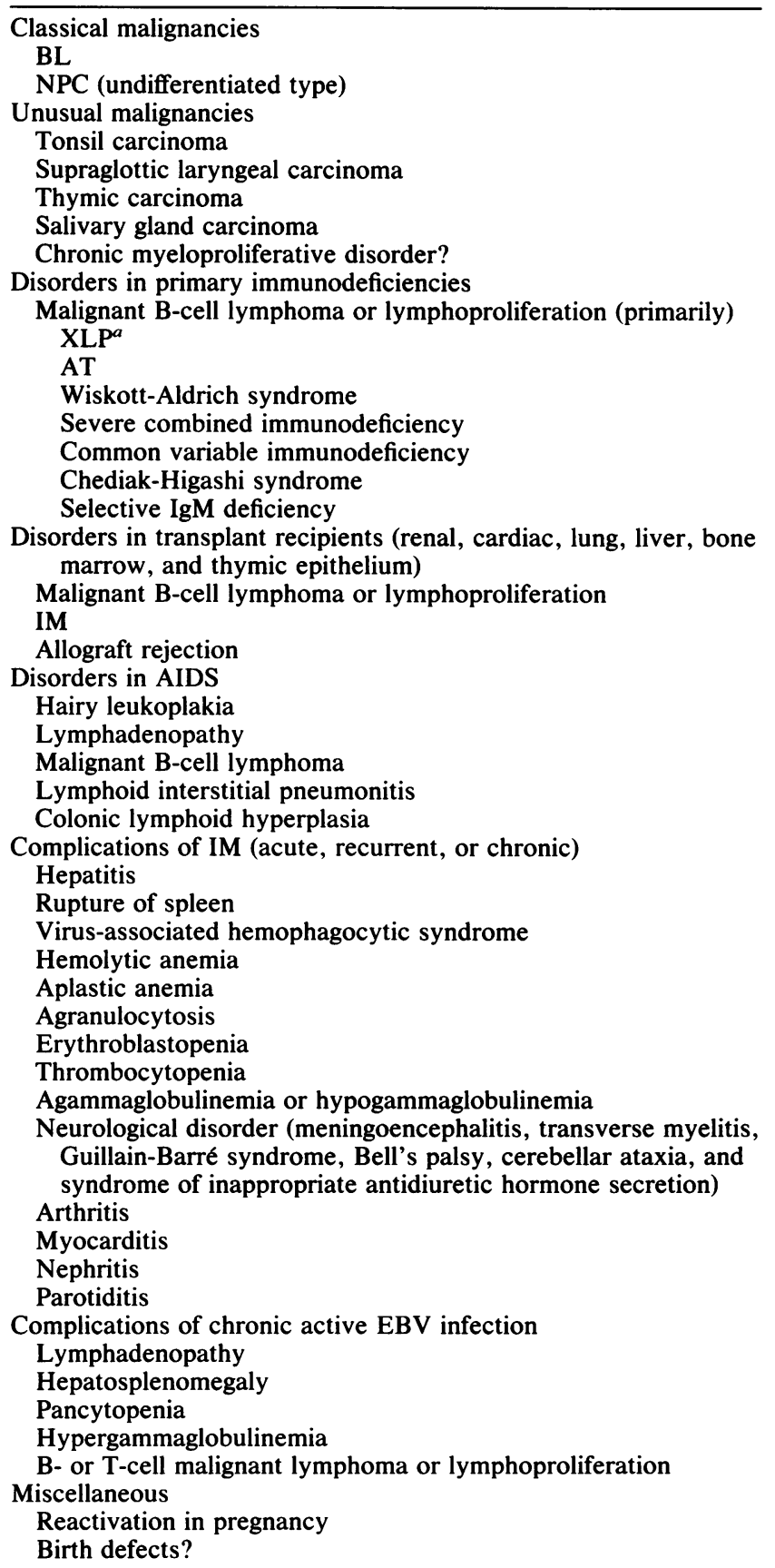

${ }^{a}$ Patients with XLP have mainly exhibited severe or fatal IM, acquired hypogammaglobulinemia, and malignant B-cell lymphoma.

growth and resistance to T-cell surveillance (80). Thus, BL has become a unique model for studying multistep carcinogenesis, and EBV appears to be the initiator of these oncogenic processes.

\section{NPC}

Tumors that arise in the nasopharynx are mostly undifferentiated carcinomas (96). In southeast China, NPC is the most prevalent tumor in males, constituting about $20 \%$ of all 
cancers (20). Genetic and certain cultural patterns predispose to the tumor. Cantonese Chinese immigrants to the United States have a lower incidence in the second generation, lower than their relatives in China, but the incidence remains higher than that of Caucasian Americans (20). Eating salted fish containing appreciable quantities of nitrosodimethylamines and other environmental factors may be etiological factors in the development of NPC (20). The use of Euphorbiaceae plant extracts in Chinese traditional medicine, which include phorbol esters that may induce replication of EBV, could also cause the development of NPC (20, 49). It has been demonstrated that EBV DNA and EBNA can be detected in NPC $(20,106)$. The etiological association between the virus and the tumor is supported by finding elevated IgG and IgA antibodies against VCA and EA-D in these patients. Recently, IgA antibodies against EA-D have been useful in establishing the diagnosis and prognosis of NPC in patients (20). Hundreds of thousands of Chinese at risk for NPC are routinely screened serologically for NPC.

\section{IM}

Primary infection by EBV is predominantly silent in early childhood. In contrast, IM is often a dramatic event when infection occurs in persons 10 to 30 years of age. "Glandular fever" was described by Emil Pfeiffer in 1889 (73). The name "infectious mononucleosis" was first used by T. P. Sprunt and F. A. Evans in 1920 (91). The disease has an insidious onset and the typical patient with IM exhibits a sore throat, fever, severe fatigue, enlarged cervical lymph nodes, and often splenomegaly (25). These signs and symptoms are due to an ongoing immunological struggle between infected $B$ cells and responding NK and T cells. Resolution generally occurs within 1 month, but sometimes long-lasting fatigue persists $(20,25)$. Some of the complications observed include hemolytic anemia, erythrocyte aplasia, thrombocytopenia, virus-associated hemophagocytic syndrome, agranulocytosis, aplastic anemia, acquired agammaglobulinemia, and immune complex deposition in tissues. The other complications arise from the invasion of lymphocytes into various organs leading to meningoencephalitis, transverse myelitis, Guillain-Barré syndrome, Bell's palsy, or cerebellar ataxia involving the central nervous system. Fulminant hepatitis, arthritis, myocarditis, and nephritis also may occur $(25,42)$.

As mentioned before, an estimated $90 \%$ of all cases of the mononucleosis syndrome are caused by EBV, 5 to $7 \%$ are due to cytomegalovirus, $1 \%$ are due to $T$. qondii, and, exceptionally, other cases are due to hepatitis virus, rubella virus, herpes simplex virus, or adenoviruses $(25,42)$. The sera from patients with IM are characterized by containing both IgM and IgG antibodies to VCA, IgG antibodies to EA-D, and an absence of antibodies to EBNA, besides the usual presence of IgM heterophil antibodies (42).

\section{Chronic Mononucleosis Syndrome}

Forty years ago, Isaacs described a prolonged clinical course of IM lasting from months to years (48). During this decade, several groups have described a protracted illness usually preceded by IM, but with persistent fatigue, headaches, myalgia, lymphadenopathy, and low-grade fever (22, $53,58,74,92,99)$. This syndrome of unknown etiology is currently the subject of a great deal of interest. The syndrome appears to be linked to EBV, because many of the patients had EBV antibody profiles that suggest reactivation
$(22,53,92,99)$. However, in a recent study, EBV was shown not to be related to an endemic form of chronic mononucleosislike disease with the apparent lack of correlation between EBV antibody titers and the presence of chronic fatigue symptoms (46).

It is proposed that "chronic mononucleosis" is a syndrome that develops for many months and years following typical heterophil-positive acute IM with serologic evidence of primary EBV infection (58). In contrast, the patients with "chronic fatigue syndrome" do not have an illness that began as acute IM, and the common major symptom is persistent fatigue (58).

Rare patients with chronic mononucleosis syndrome demonstrate severe symptoms associated with active EBV infection. These patients, usually children and young adults, develop life-threatening complications over the course of months to several years. The patients show extremely high IgG antibody titers to VCA and EA-D, while antibodies to EBNA remain at normal or subnormal levels. They tend to experience pancytopenia and polyclonal hypergammaglobulinemia. The EBV genome has also been detected in tissues from these patients (69). Furthermore, a defective nontransforming strain of EBV was isolated from a child with this syndrome, suggesting that the generation of virus strains with atypical genomes may be a common phenomenon in certain patients (1). Recently, we have detected both adenovirus type 2 and EBV genomes in affected tissues in a patient with a severe type of chronic active EBV infection, who developed generalized lymphadenopathy, hepatosplenomegaly, and hemorrhagic colonic ulcers (M. Okano, G. M. Thiele, J. R. Davis, W. M. Nauseef, F. Mitros, and D. T. Purtilo, Ann. Intern. Med., in press). The combination of these two lymphotropic viruses may be responsible for the development of the disease in this patient. Although there is little doubt that EBV caused these rare cases, the precise mechanisms remain unclear.

Patients with chronic active EBV infection do not always show obvious immunodeficiency (69). However, the patterns of EBV-specific antibodies and the presence of EBV genome in tissues strongly suggest that these patients have a subtle immunodeficiency to EBV. In some of the patients with chronic active EBV infection who demonstrated excessively high antibody titers to VCA and EA-D, the change from dominant antibody levels of EBNA-2 to dominant levels of EBNA-1 was delayed or prevented (43).

\section{EBV-INDUCED DISORDERS IN IMMUNODEFICIENT PATIENTS}

Control of EBV replication in vivo is mediated primarily by EBV-specific cytotoxic T cells and by specific antibodies directed against virally-determined antigens $(42,81)$. ADCC and augmented NK cell activity may play accessory roles (81). A delicate balance prevails between the virus infected cells and host defenses that results in a spectrum of human disease. EBV is associated with abnormal lymphoid proliferations among immunocompromised patients.

We discuss herein some life-threatening EBV infections in inherited and acquired immunodeficiency (Table 4).

\section{XLP}

Characteristics of X-linked lymphoproliferative syndrome (XLP) were first described in 1975 in males of the Duncan family in whom the syndrome manifested as an inherited immunodeficiency with fatal or chronic IM, acquired hypo- 
gammaglobulinemia, or malignant lymphoma after infection with EBV (75). The registry of XLP now contains more than 200 patients within 52 unrelated kindreds with the syndrome (34; unpublished data). Because they fail to control B- and T-cell lymphoproliferative responses to EBV, especially by cytotoxic T cells, NK cells, and suppressor T cells, twothirds of the males with XLP succumb to severe or fatal IM. Immunohistochemical studies of lesions in the liver and bone marrow reveal EBV-carrying B cells admixed with suppressor T cells and fewer numbers of NK cells $(34,60,77 ; \mathrm{D}$. T. Purtilo, M. Okano, G. Thiele, J. Davis, and H. Grierson, in Proceedings of an International Colloquium on Lymphoid Malignancy, in press). These uncontrolled lymphoid cells produce lesions in tissues, resulting in fulminant hepatitis or the virus-associated hemophagocytic syndrome in bone marrow. In the one-third of patients who survive primary EBV infection, excessive suppression of B cells by suppressor $\mathrm{T}$ cells leads to acquired hypogammaglobulinemia or agammaglobulinemia (34). In contrast, about $20 \%$ of patients with sustained polyclonal B-cell proliferation evoked by EBV develop B-cell malignancy due to molecular or cytogenetic alterations within a clone of cells (37). About $85 \%$ of patients die by 10 years of age and $100 \%$ die by 40 years of age (34). Patients studied in early and late childhood prior to infection with EBV have subtle immune defects in response to tetanus and $\phi$ X174 antigens $(66 ;$ J. Hawk, H. L. Grierson, G. M. Thiele, M. Bicak, and D. T. Purtilo, submitted for publication). Despite these defects, the patients with XLP show no vulnerability to infectious agents other than EBV. The extensive, progressive immunological defects in XLP are triggered by infection with EBV.

Recent studies have demonstrated that the mutation responsible for XLP is genetically linked to a restriction fragment-length polymorphism detected with the DXS42 probe (from chromosome Xq24-q27) (89). This restriction fragment-length polymorphism analysis may make it possible to predict which members of a family with XLP are carrier females and to diagnose the syndrome prenatally.

\section{AT and Other Primary Immunodeficiencies}

Ataxia telangiectasia (AT) is an autosomal recessive disorder characterized by progressive cerebellar ataxia, oculocutaneous telangiectasia, recurrent sinopulmonary infections, and a variable immunodeficiency (6). Patients with AT are also predisposed to malignancies, mainly T-cell leukemia, B-cell lymphoma, Hodgkin's disease, and gastric adenocarcinoma $(6,90)$. The increased occurrences of chromosomal breakage and cytogenetic rearrangement are linked with the evolution of a clone of cells that has been regarded as being premalignant (38). Furthermore, these patients have defective responses to EBV, often associated with increased IgG antibodies to VCA and EA-D, but low or nondetectable antibodies to EBNA $(3,50,68,77)$. Recently, EBV-carrying lymphoproliferative diseases have been documented in patients with AT $(68,85)$. The immunodeficiency in AT is a combined $\mathrm{T}$ - and B-cell process which is progressive (68).

Other patients with primary immunodeficiency disorders, such as Wiskott-Aldrich syndrome, severe combined immunodeficiency post-bone marrow transplantation, and common variable immunodeficiency post-thymic epithelium transplantation, and individuals with Chediak-Higashi syndrome develop EBV-induced lymphoproliferative diseases $(62,67,79,86)$.

\section{Organ Transplant Recipients}

EBV causes abnormal lymphoproliferative diseases in organ transplant recipients including those with renal, cardiac, lung, liver, bone marrow, and thymic epithelium transplants $(35,79,86)$. Transition from polyclonal to monoclonal B-cell proliferative lesions has been documented in a renal allograft patient (36). Furthermore, immunoglobulin gene rearrangement studies have revealed that some of the lymphomas in transplant recipients may even be biclonal or multiclonal (16). This increased incidence of lymphoproliferative diseases has been postulated to be due to impaired immunosurveillance, chronic antigenic stimulation from the allograft, or direct oncogenic effects of immunosuppressive drugs (35). When cyclosporine $A$ is added to in vitro cultures of EBV-infected peripheral blood lymphocytes, a marked suppression of memory $\mathrm{T}$-cell activity and an enhancement of the outgrowth of EBV-infected B cells occur (5). In general, immunosuppressive drugs used to prevent organ allograft rejection suppress immunity and predispose the individual to all herpesvirus infections (cytomegalovirus, herpes simplex virus, and varicella-zoster virus, as well as EBV).

Defective immunosurveillance seems to allow B-cell proliferation to persist due to EBV infection. Following its discovery, the use of cyclosporine A resulted in the development of lymphoproliferative diseases (11). Subsequently, the dose of cyclosporine $\mathrm{A}$ has been decreased and only about $1 \%$ of transplant recipients experience lymphoproliferative diseases induced by $\operatorname{EBV}(12,35)$. The degree of immunosuppression rather than the particular type of immunosuppressive agent is probably the most important predisposing factor.

\section{AIDS}

Acquired immunodeficiency syndrome (AIDS) is caused by human immunodeficiency virus and renders persons vulnerable to a multitude of infections including viral, protozoan, fungal, and mycobacterial diseases (26). Indeed, there are increasing reports the EBV is associated with the development of five lesions found in AIDS patients: (i) hairy leukoplakia; (ii) lymphadenopathy; (iii) malignant lymphoma; (iv) lymphoid interstitial pneumonitis; and (v) colonic lymphoid hyperplasia (Purtilo et al., in press). Furthermore, human immunodeficiency virus and EBV have been shown to coinfect B cells (63). Hairy leukoplakia is caused by productive EBV infection in the epithelium of the tongue of some homosexual males (33). Other noteworthy lesions include interstitial lymphoid infiltrative lesions in the lungs of children with AIDS (54). Diffuse non-Hodgkin's lymphomas and BL commonly occur in patients with AIDS. The EBV genome is commonly encountered in these lymphomas, and the patients frequently showed elevated IgG antibody titers to VCA and EA-R (93; Purtilo et al., in press).

Both primary and secondary acquired immunodeficiency disorders allow activation of EBV. Owing to the increased frequency of iatrogenic immunodeficiency and the spread of AIDS, we can anticipate that an increasing number of patients with EBV-induced diseases will continue to appear.

\section{CONCLUDING REMARKS}

Since EBV was discovered in 1964 , it has been etiologically implicated in an increasing number of human diseases. It is generally considered to be the first possible human 
oncogenic virus. Following infection with EBV, specific molecular and cytogenetic alterations may occur in an infected B cell (56). Thus, a clone of malignant B cells is formed which leads to the development of $\mathrm{BL}$. These malignant B cells may also easily escape from the host immunosurveillance by the down-regulation of the target epitopes for cytotoxic $\mathrm{T}$-cell recognition (80). Immunodeficiency permits EBV to cause sustained B-cell proliferation which increases the chances that an aberrant molecular event will ensue in an EBV-infected B cell. While this scenario has become well accepted for BL, the mechanisms responsible for the induction of NPC remain an enigma and the subject of many investigations.

Studies linking BL and NPC with EBV occurred in the late 1960 s, and lymphoproliferative in both primary and acquired immunodeficiencies were reported in the mid- and late 1970s. The ubiquity and apparent ability of EBV to induce malignancy challenge scientists and clinicians focusing on virology, oncology, cell biology, and immunology. The study of latent or activated EBV infection in different susceptible individuals will teach us about normal mechanisms of virus-host interactions.

As described herein, EBV may be expressed clinically in many ways depending on the immune status of the host. When this virus-host balance is disturbed, a broad spectrum of EBV-associated diseases may develop. This is not surprising as many other lymphotropic viruses produce a variety of diseases (Editorial, Lancet i:217-219, 1988).

\section{ACKNOWLEDGMENTS}

We thank the colleagues in the Immunovirology Laboratory for their assistance and Karen Spiegel for preparation of this manuscript.

This work was supported in part by Public Health Service grants CA30196 and CA36727, both from the National Cancer Institute, the State of Nebraska Department of Health (LB506), and the Lymphoproliferative Research Fund.

\section{LITERATURE CITED}

1. Alfieri, C., and J. H. Joncas. 1987. Biomolecular analysis of a defective nontransforming Epstein-Barr virus (EBV) from a patient with chronic active EBV infection. J. Virol. 61:33063309.

2. Andiman, W., L. Gradoville, L. Heston, R. Neydorfi, M. E. Savage, G. Kitchingman, D. Shedd, and G. Miller. 1983. Use of cloned probes to detect Epstein-Barr viral DNA in tissues of patients with neoplastic and lymphoproliferative diseases. J. Infect. Dis. 148:967-977.

3. Berkel, A. I., W. Henle, G. Henle, G. Klein, F. Ersoy, and O. Sanal. 1979. Epstein-Barr virus-related antibody patterns in ataxia-telangiectasia. Clin. Exp. Immunol. 35:196-201.

4. Biggar, R. J., C. Gardiner, E. T. Lennette, W. E. Collins, F. K. Nkrumah, and W. Henle. 1981. Malaria, sex, and place of residence as factors in antibody response to Epstein-Barr virus in Ghana, west Africa. Lancet ii:115-118.

5. Bird, A. G., S. M. McLachlan, and S. Britton. 1981. Cyclosporin A promotes spontaneous outgrowth in vitro of Epstein-Barr virus-induced B-cell lines. Nature (London) 289:300-301.

6. Border, E. 1975. Ataxia telangiectasia: some historic, clinical and pathologic observations, p. 255-270. In D. Bergsma, R. A. Good, and J. Feinstad (ed.), Immunodeficiency in man and animals. The Williams \& Wilkins Co., Baltimore.

7. Bornkamm, G. W., H. Delius, U. Zimber, J. Hudewentz, and M. A. Epstein. 1980. Comparison of Epstein-Barr virus strains of different origin by analysis of the viral DNAs. J. Virol. 35:603-618.

8. Bornkamm, G. W., M. Knebel-Doeberitz, and G. M. Lenoir. 1984. No evidence for differences in the Epstein-Barr virus genome carried in Burkitt lymphoma cells and nonmalignant lymphoblastoid cells from the same patients. Proc. Natl. Acad. Sci. USA 81:4930-4934.

9. Burkitt, D. 1958. A sarcoma involving the jaws in African children. Br. J. Surg. 46:218-224.

10. Burkitt, D. P. 1969. Etiology of Burkitt's lymphoma: an alternative to a vectored virus. J. Natl. Cancer Inst. 42:1928.

11. Calne, R. Y., K. Rolles, D. J. G. White, S. Thiru, D. B. Evans, P. McMaster, D. C. Dunn, G. N. Craddock, R. G. Henderson, S. Aziz, and P. Lewis. 1979. Cyclosporin A initially as the immunosuppressant in 34 recipients of cadaveric organs: 34 kidneys, 2 pancreases, and 2 livers. Lancet ii:1033-1036.

12. Calne, R. Y., D. J. G. White, and D. B. Evans. 1981. Cyclosporin $\mathrm{A}$ in cadaveric organ transplantation. Br. Med. J. 282:934-936.

13. Chang, R. S., J. P. Lewis, and C. F. Abildgaard. 1973. Prevalence of oropharyngeal excretors of leukocyte-transforming agents among a human population. N. Engl. J. Med. 289:1325-1329.

14. Cheah, M. S. C., T. J. Ley, S. R. Tronick, and K. C. Robbins. 1986. $\mathrm{fgr}$ proto-oncogene mRNA induced in B lymphocytes by Epstein-Barr virus infection. Nature (London) 319:238-240.

15. Cleary, M. L., J. Chao, R. Warnke, and J. Sklar. 1984. Immunoglobulin gene rearrangement as a diagnostic criterion of B-cell lymphoma. Proc. Natl. Acad. Sci. USA 81:593-597.

16. Cleary, M. L., and J. Sklar. 1984. Lymphoproliferative disorders in cardiac transplant recipients are multiclonal lymphomas. Lancet i:489-493.

17. Dambaugh, T., K. Hennessy, S. Fennewald, and E. Kieff. 1986. The virus genome and its expression in latent infection, p. 1345. In M. A. Epstein and B. G. Achong (ed.), The Epstein-Barr virus: recent advances. W. Heinemann Medical Books, London.

18. Datta, A. K., B. M. Colby, J. E. Shaw, and J. S. Pagano. 1980. Acyclovir inhibition of Epstein-Barr virus replication. Proc. Natl. Acad. Sci. USA 77:5163-5166.

19. Davidsohn, I., and C. L. Lee. 1969. The clinical serology of infectious mononucleosis, p. 177-200. In R. L. Carter and H. G. Penman (ed.), Infectious mononucleosis. Blackwell Scientific Publications, Ltd., Oxford.

20. De-Thé, G. 1982. Epidemiology of Epstein-Barr virus and associated diseases in man, p. 25-103. In B. Roizman (ed.), The herpesviruses, vol. 1. Plenum Publishing Corp., New York.

21. Dillner, J., B. Kallin, H. Alexander, I. Ernberg, M. Uno, Y. Ono, G. Klein, and R. A. Lerner. 1986. An Epstein-Barr virus (EBV)-determined nuclear antigen (EBNA5) partly encoded by the transformation-associated Bam WYH region of EBV DNA: preferential expression in lymphoblastoid cell lines. Proc. Natl. Acad. Sci. USA 83:6641-6645.

22. DuBois, R. E., J. K. Seeley, I. Brus, K. Sakamoto, M. Ballow, S. Harada, T. A. Bechtold, G. Pearson, and D. T. Purtilo. 1984. Chronic mononucleosis syndrome. South. Med. J. 77:13761382.

23. Epstein, M. A., B. G. Achong, and Y. M. Barr. 1964. Virus particles in cultured lymphoblasts from Burkitt's lymphoma. Lancet i:702-703.

24. Ernberg, I., B. Kallin, J. Dillner, K. Falk, B. Ehlin-Henrikson, M. L. Hammarskjold, and G. Klein. 1986. Lymphoblastoid cell lines and Burkitt-lymphoma-derived cell lines differ in the expression of a second Epstein-Barr virus encoded nuclear antigen. Int. J. Cancer 38:729-737.

25. Evans, A. S. 1978. Infectious mononucleosis and related syndrome. Am. J. Med. Sci. 276:325-339.

26. Fauci, A. S., H. Masur, E. P. Gelmann, P. D. Markham, B. H. Hahn, and H. C. Lane. 1985. The acquired immunodeficiency syndrome: an update. Ann. Intern. Med. 102:800-813.

27. Fingeroth, J. D., J. J. Weis, T. F. Tedder, J. L. Srominger, P. A. Biro, and D. T. Fearon. 1984. Epstein-Barr virus receptor of human B lymphocytes is the C3d receptor CR2. Proc. Natl. Acad. Sci. USA 81:4510-4514.

28. Fleisher, G., E. T. Lennette, G. Henle, and W. Henle. 1979. 
Incidence of heterophil antibody responses in children with infectious mononucleosis. J. Pediatr. 94:723-728.

29. Flug, F., P. G. Pelicci, F. Bonetti, D. M. Knowles II, and R. Dalla-Favera. 1985. T-cell receptor gene rearrangements as markers of lineage and clonality in T-cell neoplasms. Proc. Natl. Acad. Sci. USA 82:3460-3464.

30. Gardella, T., P. Medveczky, T. Sairenji, and C. Mulder. 1984. Detection of circular and linear herpesvirus DNA molecules in mammalian cells by gel electrophoresis. J. Virol. 50:248-254.

31. Gerber, P., M. Nonoyama, S. Lucas, E. Perlin, and L. I. Goldstein. 1972. Oral excretion of Epstein-Barr virus by healthy subjects and patients with infectious mononucleosis. Lancet ii:988-989.

32. Gerber, P., R. H. Purcell, E. N. Rosenblum, and J. H. Walsh. 1969. Association of EB-virus infection with the post-perfusion syndrome. Lancet i:593-596.

33. Greenspan, J. S., D. Greenspan, E. T. Lennette, D. I. Abrams, M. A. Conant, V. Petersen, and U. K. Freese. 1985. Replication of Epstein-Barr virus within the epithelial cells of oral "hairy" leukoplakia, an AIDS-associated lesion. N. Engl. J. Med. 313:1564-1571.

34. Grierson, H., and D. T. Purtilo. 1987. Epstein-Barr virus infections in males with the X-linked lymphoproliferative syndrome. Ann. Intern. Med. 106:538-545.

35. Hanto, D. W., G. Frizzera, K. J. Gajl-Peczalska, and R. L. Simmons. 1985. Epstein-Barr virus, immunodeficiency, and B cell lymphoproliferation. Transplantation 39:461-472.

36. Hanto, D. W., K. J. Gajl-Peczalska, J. Kazimiera, G. Frizzera, D. C. Arthur, H. H. Balfour, K. McClain, R. L. Simmons, and J. S. Najarian. 1983. Epstein-Barr virus (EBV) induced polyclonal and monoclonal B-cell lymphoproliferative diseases occurring after renal transplantation. Ann. Surg. 198:356-369.

37. Harrington, D. S., D. D. Weisenburger, and D. T. Purtilo. 1987. Malignant lymphoma in the X-linked lymphoproliferative syndrome. Cancer 59:1419-1429.

38. Hecht, F., B. K. McCaw, and R. D. Koller. 1973. Ataxiatelangiectasia clonal growth of translocation lymphocyte. N. Engl. J. Med. 289:286-289.

39. Henle, G., W. Henle, and C. A. Horwitz. 1974. Antibodies to Epstein-Barr virus-associated nuclear antigen in infectious mononucleosis. J. Infect. Dis. 130:231-239.

40. Henle, G., E. T. Lennett, M. A. Alspaugh, and W. Henle. 1979. Rheumatoid factor as a cause of positive reactions in tests for Epstein-Barr virus specific IgM antibodies. Clin. Exp. Immunol. 36:415-422.

41. Henle, W., and G. Henle. 1981. Epstein-Barr virus specific serology in immunologically compromised individuals. Cancer Res. 41:4222-4225.

42. Henle, W., and G. Henle. 1982. Immunology of Epstein-Barr virus, p. 209-252. In B. Roizman (ed.), The herpesviruses, vol. 1. Plenum Publishing Corp., New York.

43. Henle, W., G. Henle, J. Andersson, I. Ernberg, G. Klein, C. A. Horwitz, G. Marklund, L. Rymo, C. Wellinder, and S. E. Straus. 1987. Antibody responses to Epstein-Barr virus-determined nuclear antigen (EBNA)-1 and EBNA-2 in acute and chronic Epstein-Barr virus infection. Proc. Natl. Acad. Sci. USA 84:570-574.

44. Hennessy, K., S. Fennewald, M. Hummel, T. Cole, and E. Kieff. 1984. A membrane protein encoded by Epstein-Barr virus in latent growth transforming infection. Proc. Natl. Acad. Sci. USA 81:7207-7211.

45. Ho, J. H. C. 1978. An epidemologic and clinical study of nasopharyngeal carcinoma. Int. J. Radiol. Oncol. Biol. Phys. 4:181-198.

46. Holmes, G. P., J. E. Kaplan, J. A. Stewart, B. Hunt, P. F. Pinsky, and L. B. Schonberger. 1987. A cluster of patients with a chronic mononucleosis-like syndrome: is Epstein-Barr virus the cause? J. Am. Med. Assoc. 257:2297-2301.

47. Horwitz, C. A., W. Henle, G. Henle, and H. Schmitz. 1975. Clinical evaluation of patients with infectious mononucleosis and development of antibodies to the $\mathrm{R}$ component of the Epstein-Barr virus-induced early antigen complex. Am. J. Med. 58:330-338.
48. Isaacs, R. 1948. Chronic infectious mononucleosis. Blood 3: 858-861.

49. Ito, Y., M. Kawanishi, T. Hirayama, and S. Takabayashi. 1981. Combined effect of the extracts from Croton tiglium, Euphorbia lathyris or Euphorbia tizucalli and n-butyrate on EpsteinBarr virus expression in human lymphoblastoid P3HR-1 and Raji cells. Cancer Lett. 12:175-180.

50. Joncas, J., N. LaPointe, F. Gervais, and M. Leyritz. 1977. Unusual prevalence of Epstein-Barr virus early antigen (EBVEA) antibody in ataxia-telangiectasia. J. immunol. 119:18571859.

51. Jondal, M., G. Klein, M. B. A. Oldstone, V. Bokish, and E. Yefenof. 1976. An association between complement and Epstein-Barr virus receptors on human lymphoid cells. Scand. J. Immunol. 5:401-410.

52. Jondal, M., E. Svedmyr, E. Klein, and G. Klein. 1976. Comparative leukemia research 1975. Bibl. Haematol. (Basel) 43: 265-271.

53. Jones, J., C. Ray, L. Minnich, M. J. Hicks, R. Kibler, and D. O. Lucas. 1985. Evidence for active Epstein-Barr virus infection in patients with persistent unexplained illness: elevated antiearly antigen antibodies. Ann. Intern. Med. 102:1-6.

54. Joshi, V. V., S. Kauffman, J. M. Oleske, S. Fikrig, T. Denny, C. Gadol, and E. Lee. 1987. Polyclonal polymorphic B-cell lymphoproliferative disorder with prominent pulmonary involvement in children with acquired immune deficiency syndrome. Cancer 59:1455-1462.

55. Katz, B. Z., J. C. Niederman, B. A. Olson, and G. Miller. 1988. Fragment length polymorphisms among independent isolates of Epstein-Barr virus from immunocompromised and normal hosts. J. Infect. Dis. 157:299-308.

56. Klein, G. 1979. Lymphoma development in mice and humans: diversity of initiation is followed by convergent cytogenetic evolution. Proc. Natl. Acad. Sci. USA 76:2442-2446.

57. Klein, G., E. Svedmyr, M. Jondal, and P. O. Persson. 1976. EBV-determined nuclear antigen (EBNA)-positive cells in the peripheral blood of infectious mononucleosis patients. Int. J. Cancer 17:21-26.

58. Komaroff, A. 1987. The "chronic mononucleosis" syndrome. Hosp. Pract. 22:71-75.

59. Luka, J., R. C. Chase, and G. R. Pearson. 1984. A sensitive enzyme-linked immunosorbent assay (ELISA) against major EBV-associated antigens. I. Correlation between ELISA and immunofluorescence titers using purified antigens. J. Immunol. Methods 67:145-156.

60. Markin, R. S., J. Linder, K. Zuerlein, H. L. Grierson, B. Brichacek, and D. T. Purtilo. 1987. Hepatitis in fatal infectious mononucleosis. Gastroenterology 93:1210-1217.

61. Menezes, J., M. Jondal, W. Leibold, and G. Dorval. 1976. Epstein-Barr virus interactions with human lymphocyte subpopulations, virus adsorptions, kinetics of expression of Epstein-Barr virus-associated nuclear antigen, and lymphocyte transformation. Infect. Immun. 13:303-310.

62. Merino, F., G. Klein, W. Henle, P. Ramirez-Doque, M. Forsgren, and C. Amesty. 1983. Elevated antibody titers to EpsteinBarr virus and low natural killer cell activity in patients with Chediak-Higashi syndrome. Clin. Immunol. Immunopathol. 27:326-339.

63. Montagnier, L., J. Gruest, S. Chamaret, C. Dauget, C. Axler, D. Guetard, M. T. Nugeyer, F. Barre-Sinoussi, J. C. Chermann, J. B. Brunet, D. Klatzman, and J. C. Gluckman. 1984. Adaptation of lymphadenopathy associated retrovirus (LAV) to replication in EBV-transformed B lymphoblastoid cell lines. Science 225:63-66.

64. Moss, D., A. Rickinson, and J. Pope. 1978. Long-term T-cellmediated immunity to Epstein-Barr virus in man. I. Complete regression of virus-induced transformation in cultures of seropositive donor leukocytes. Int. J. Cancer 22:662-668.

65. Nilsson, K. 1979. The nature of lymphoid cell lines and their relationship to the virus, p. 225-281. In M. A. Epstein and B. G. Achong (ed.), The Epstein-Barr virus. Springer-Verlag, Berlin.

66. Ochs, H. D., J. L. Sullivan, R. J. Wedgwood, J. K. Seeley, K. 
Sakamoto, and D. T. Purtilo. 1983. X-linked lymphoproliferative syndrome: abnormal antibody responses to bacteriophage OX174, p. 321-323. In R. Wedgwood and F. Rosen (ed.), Primary immunodeficiency disease. Alan R. Liss, Inc., New York.

67. Okano, M., F. Mizuno, T. Osato, Y. Takahashi, Y. Sakiyama, and S. Matsumoto. 1984. Wiskott-Aldrich syndrome and Epstein-Barr virus-induced lymphoproliferation. Lancet ii:933934.

68. Okano, M., T. Osato, S. Koizumi, S. Imai, T. Aya, S. Fujiwara, F. Mizuno, Y. Sakiyama, S. Matsumoto, O. Sugawara, K. Uchida, M. Miwa, K. Hirai, T. Miyashita, and C. Iwata. 1986. Epstein-Barr virus infection and oncogenesis in primary immunodeficiency. AIDS Res. 2:115-119.

69. Okano, M., Y. Sakiyama, S. Matsumoto, F. Mizuno, and T. Osato. 1986. Unusual lymphoproliferation associated with chronic active Epstein-Barr virus infection. AIDS Res. 2:121123.

70. Pagano, J. S., and E. S. Huang. 1974. Application of RNADNA cytohybridization to viral diagnostics, p. 279-299. In E. Kurstak and R. Morisset (ed.), Viral immunodiagnosis. Academic Press, Inc., New York.

71. Paul, J. R., and W. W. Bunnell. 1932. The presence of heterophil antibodies in infectious mononucleosis. Am. J. Med. Sci. 183:91-104.

72. Pearson, G. R., and T. W. Orr. 1976. Antibody-dependent lymphocyte cytotoxicity against cells expressing Epstein-Barr virus antigens. J. Natl. Cancer Inst. 56:485-488.

73. Pfeiffer, E. 1889. Drusenfieber. Jahrb. Kinderheilkd. 29:257264.

74. Purtilo, D. T. 1987. Epstein-Barr virus: the spectrum of its manifestations in humans. South. Med. J. 80:943-947.

75. Purtilo, D. T., C. K. Cassel, J. P. S. Yang, R. Harper, S. R. Stephenson, B. H. Landing, and G. F. Vawter. 1975. X-linked recessive progressive combined variable immunodeficiency (Duncan's disease). Lancet i:935-941.

76. Purtilo, D. T., G. Manolov, Y. Manolova, S. Harada, H. Lipscomb, and E. Tatsumi. 1985. Burkitt's lymphoma: a human cancer model. IARC (Int. Agency Res. Cancer) Sci. Publ. 60:231-247.

77. Purtilo, D. T., E. Tatsumi, G. Manolov, Y. Manolova, S. Harada, H. Lipscomb, and G. Krueger. 1985. Epstein-Barr virus as an etiological agent in the pathogenesis of lymphoproliferative and aproliferative diseases in immune deficient patients. Int. Rev. Exp. Pathol. 27:113-183.

78. Raab-Traub, N., and K. Flynn. 1986. The structure of the termini of the Epstein-Barr virus as a marker of clonal cellular proliferation. Cell 47:883-889.

79. Reece, E. R., J. G. Gartner, T. A. Seemayer, J. H. Joncas, and J. S. Pagano. 1981. Epstein-Barr virus in a malignant lymphoproliferative disorder of B-cells occurring after thymic epithelial transplantation for combined immunodeficiency. Cancer Res. 41:4243-4247.

80. Rickinson, A. B. 1986. Cellular immunological responses to the virus infection, p. 75-125. In M. A. Epstein and B. G. Achong (ed.), The Epstein-Barr virus: recent advances. Heinemann, London.

81. Robinson, J. E., and G. Miller. 1982. Biology of lymphoid cells transformed by Epstein-Barr virus, p. 151-207. In B. Roizman (ed.), The herpesviruses, vol. 1. Plenum Publishing Corp., New York.

82. Roizman, B. 1982. The family herpesviridae: general description, taxonomy, and classification, p. 1-23. In B. Roizman (ed.), The herpesviruses, vol. 1. Plenum Publishing Corp., New York.

83. Rosen, A., P. Gergely, M. Jondal, G. Klein, and S. Britton. 1977. Polyclonal Ig production after Epstein-Barr virus infection of human lymphocytes in vitro. Nature (London) 267:5256.

84. Rosenberg, S. A. 1982. National Cancer Institute sponsored study of classification of non-Hodgkin's lymphomas. Summary and description of a working formulation for clinical usage. Cancer 49:2112-2135.
85. Saemundsen, A. K., A. I. Berkel, W. Henle, G. Henle, M. Anvret, O. Sanal, F. Ersoy, M. Cagler, and G. Klein. 1981. Epstein-Barr virus carrying lymphoma in a patient with ataxia telangiectasia. Br. Med. J. 282:425-427.

86. Shearer, W. T., J. Ritz, M. Finegold, C. Guerra, H. M. Rosenblatt, D. E. Lewis, M. S. Pollack, L. H. Taber, C. V. Sumaya, C. G. Grumet, M. L. Cleary, R. Warnke, and J. Sklar. 1985. Epstein-Barr virus-associated B-cell proliferations of diverse clonal origins after bone marrow transplantation in a 12-year-old patient with severe combined immunodeficiency. N. Engl. J. Med. 312:1151-1159.

87. Sixbey, J. W., J. G. Nedrud, N. Raab-Traub, R. A. Hanes, and J. S. Pagano. 1984. Epstein-Barr virus replication in oropharyngeal epithelial cells. N. Engl. J. Med. 310:1225-1230.

88. Sixbey, J. W., E. H. Vesterinen, J. G. Nedrud, N. Raab-Traub, L. A. Walton, and J. S. Pagano. 1983. Replication of EpsteinBarr virus in human epithelial cells infected in vitro. Nature (London) 306:480-489.

89. Skare, J. C., A. Milunsky, K. S. Byron, and J. L. Sullivan. 1987. Mapping the $X$-linked lymphoproliferative syndrome. Proc. Natl. Acad. Sci. USA 84:2015-2018.

90. Spector, B. D., G. S. Perry III, and J. H. Kersey. 1978. Genetically-determined immunodeficiency diseases (GDID) and malignancy: report from the immunodeficiency-cancer registry. Clin. Immunol. Immunopathol. 11:12-29.

91. Sprunt, T. P., and F. A. Evans. 1920. Mononuclear leukocytosis in reaction to acute infections (in infectious mononucleosis). Bull. Johns Hopkins Hosp. 31:410-417.

92. Straus, S., G. Tosato, G. Armstrong, T. Lawley, O. T. Preble, W. Henle, R. Davey, G. Pearson, J. Epstein, I. Brus, and M. Blaese. 1985. Persisting illness and fatigue in adults with evidence of Epstein-Barr virus infection. Ann. Intern. Med. 102:7-15.

93. Sumaya, C. V., R. N. Boswell, E. Ench, D. L. Kisner, E. M. Hersh, J. M. Reuben, and M. D. Mansell. 1986. Enhanced serological and virological findings of Epstein-Barr virus in patients with AIDS and AIDS-related complex. J. Infect. Dis. 154:864-870.

94. Sumaya, C. V., and Y. Ench. 1985. Epstein-Barr virus infectious mononucleosis in children. II. Heterophil antibody and viral-specific responses. Pediatrics 75:1011-1019.

95. Svedmyr, E., and M. Jondal. 1975. Cytotoxic effector cells specific for B cell lines transformed by Epstein-Barr virus are present within patients with infectious mononucleosis. Proc. Natl. Acad. Sci. USA 72:1622-1626.

96. Svoboda, D., K. R. Kirchner, and K. Shanmugaratnam. 1965. Ultrastructure of nasopharyngeal carcinomas in American and Chinese patients: an application of electron microscopy to geographic pathology. Exp. Mol. Pathol. 4:189-204.

97. Thiele, G., M. Bicak, H. Grierson, P. Lai, and D. T. Purtilo. 1987. Antibody reactivity to a synthetic peptide (P62) of the Epstein-Barr nuclear antigen in sera of patients with X-linked lymphoproliferative syndrome. J. Immunol. Methods 100:249 259.

98. Thorley-Lawson, D. A. 1981. The transformation of adult but not newborn human lymphocytes by Epstein-Barr virus and phytohemagglutinin is inhibited by interferon: the early suppression by T cells of Epstein-Barr virus infection is mediated by interferon. J. Immunol. 126:829-833.

99. Tobi, M., and S. Straus. 1985. Chronic Epstein-Barr virus disease: a workshop held by the National Institute of Allergy and Infectious Disease. Ann. Intern. Med. 103:951-953.

100. Tosato, G., J. Magrath, J. Koski, N. Dooley, and M. Blaese. 1979. Activation of suppressor T cells during Epstein-Barrvirus-induced infectious mononucleosis. N. Engl. J. Med. 301:1133-1137.

101. Winchester, R. J., and G. Ross. 1980 . Methods for enumerating lymphocyte populations, p. 213-228. In N. R. Rose and H. Friedman (ed.), Manual of clinical immunology, 2nd ed. American Society for Microbiology, Washington, D.C.

102. Yates, J., N. Warren, D. Reisman, and B. Sugden. 1984. A cis-acting element from the Epstein-Barr viral genome that permits stable replication of recombinant plasmid in latently 
infected cells. Proc. Natl. Acad. Sci. USA 81:3806-3810.

103. Zarling, J. M., L. Eskra, E. C. Borden, J. Horoszewicz, and W. A. Carter. 1979. Activation of human natural killer cells cytotoxic for human leukemia cells by purified interferon. J. Immunol. 123:63-70.

104. Ziegler, J. L. 1981. Burkitt's lymphoma. N. Engl. J. Med. 305:735-745.

105. Zimber, U., H. K. Adldinger, G. M. Lenoir, M. Vuillaume,
M. V. Knebel-Doeberitz, G. Laux, C. Desgranges, P. Wittmann, U. Freese, U. Schneider, and G. W. Bornkamm. 1986. Geographical prevalence of two types of Epstein-Barr virus. Virology 154:56-66.

106. Zur Hausen, H., H. Schulte-Holthausen, G. Klein, W. Henle, G. Henle, P. Clifford, and L. Santesson. 1970. EBV DNA in biopsies of Burkitt's tumors and anaplastic carcinoma of the nasopharynx. Nature (London) 228:1056-1058. 